\title{
The Relationship between the Utilization of Chemical Laboratory Facilities and Chemical Learning Disipline with Achievement of Chemical Learning Students Class XII of SMA Negeri 1 Sorong
}

\author{
Vina N. Van Harling ${ }^{1, *}$, Markus Dwiyanto Tobi Sogen ${ }^{2}$ \\ ${ }^{1}$ Mechanical Engineering, Catholic polytechnic Saint Paul, Sorong, West Papua, Indonesia \\ ${ }^{2}$ Electrical Engineering, Catholic polytechnic Saint Paul, Sorong, West Papua, Indonesia
}

Copyright $\subseteq 2019$ by authors, all rights reserved. Authors agree that this article remains permanently open access under the terms of the Creative Commons Attribution License 4.0 International License

\begin{abstract}
This study aims to determine the significance of the relationship between the use of chemical laboratory facilities and student chemistry learning achievements and the significance of the discipline of learning chemistry students with chemistry learning achievements. The populations in this study were students of class XII Science in SMA N 1 Sorong. A total of 97 students were taken using the Proportionate Random Sampling technique. The data collection methods used were questionnaires and documentation studies. The results showed that: 1) there was no positive and significant relationship between the use of chemical laboratory facilities and student chemistry learning achievements; and 2) there is no positive and significant relationship between the discipline of chemistry learning students and students' chemistry learning achievement.
\end{abstract}

Keywords Utilization of Laboratory Facilities, Learning Discipline, Learning Achievement

\section{Introduction}

Education is considered as the most valuable investment in the form of improving the quality of human resources for the development of a nation. The contribution of education to nation-building is certainly not just the implementation of education but quality education, both in terms of input, process, output and outcome. Obtaining quality education requires qualified teachers who are able to reach the standard of the education process. Teachers can be said to be of quality if they are able to produce students who are knowledgeable [1][18].

The curriculum currently applied in Indonesia for education is the 2013 curriculum which emphasizes the formation of attitudes, skills and knowledge, so that it is expected to produce graduates who are productive, creative, innovative, and affective.

In the process of learning in schools will become more active and creative when utilizing the functions of the learning facilities provided by the school, one of which is a laboratory. School laboratories have the meaning as a place to conduct experiments and research related to the learning process, which has a function as a place for students to experiment, discuss experiments, see demonstrations from teachers, and also function as a place to listen explanations of the concepts of a subject.

Chemistry is a branch of science, in this way learning must involve students in their learning experiences by practicing in a laboratory. Amien [2] suggested that practicum is one of the laboratory activities that are very instrumental in supporting the success of the science teaching and learning process. In the research results of Penner, Lehrer and Schuble [3], Roth, Choudhury [4] writes that experience in school laboratories can provide opportunities for students if the teacher allows them to be intellectually involved and with experiential experience can build scientific concepts in their learning communities in the classroom.

Utilization of laboratories together with existing facilities in public schools is through practical activities, through practicum, students can develop their abilities including: 1) planning: pouring ideas that can be traded, designing dialogue, 2) selection: manipulating, directing, and collecting data, 3) interpretation: data processing, drawing conclusions, application of concepts, 4) communication: reporting and receiving information [5][17].

Rahayu [6] stated that seven activities carried out in the 
experiment include observing, classifying or explaining activities, measuring using tools, communicating results, interpreting, predicting, analyzing and concluding. This statement is supported by Hofstein and Luneta [4] which state that science laboratories can develop students' understanding of scientific concepts, skills in experimentation, and their way of thinking. Thus in the process of learning chemistry, the more students do practical work, the more students will understand the material provided during learning so that their chemistry learning achievement will be better.

For example, in a practicum, the difference oxidation power of halogen against $\mathrm{Fe}^{2+}$ and the reduction power of halide ion on $\mathrm{Fe}^{3+}$ ions. Where during the practicum, besides utilizing the laboratory building also used laboratory equipment such as test tubes, measuring pipettes, test tube racks, $\mathrm{FeSO}_{4}$ solution, $\mathrm{Fe}_{2}\left(\mathrm{SO}_{4}\right)_{3}$ solution, $\mathrm{NaCl}$, $\mathrm{NaBr}, \mathrm{KI}, \mathrm{KSCN}, \mathrm{Cl}_{2}, \mathrm{Br}_{2}$ and $\mathrm{I}_{2}$ solutions. Utilization of laboratory facilities in this study in the form of buildings, consumables, tools and materials, as well as other equipment needed during the practicum takes place.

Utilization of laboratories and facilities in schools generally is through practical activities, through practicum, students can develop their abilities including: 1) planning: pouring ideas that can be tested, designing investigations, 2) appearance: manipulating, observing , and data collection, 3) interpretation: data processing, drawing conclusions, applying concepts, 4) communication: reporting and receiving information [5][16]

In addition to laboratory use, discipline is a factor that also influences chemistry learning achievement. Discipline comes from within students, students who have a disciplined attitude in learning will show their readiness to attend class lessons, do homework assignments and have complete learning such as books and other learning tools. On the other hand, students who lack discipline in learning do not show readiness to follow lessons, don't do assignments, play truant, don't accomplish homework, and don't have complete learning [7]. The higher the level of student learning discipline, the better the learning achievement achieved, because discipline can create a comfortable and conducive learning atmosphere, so that their learning goals will be achieved.

\section{Objective}

Thus, the aims of this research are:

1. To find out whether there is a positive and significant relationship between the utilization of chemical laboratory facilities with the chemistry learning achievement of student's class XII Science of SMA Negeri 1 Sorong

2. To find out whether there is a positive and significant relationship between students' chemical learning discipline and chemistry learning achievement of student's class XII Science of SMA Negeri 1 Sorong

\section{Materials and Methods}

\subsection{Type of Research}

This type of research conducted by the author in this study is correlations research that is research to try to find the relationship between two or more variables used. The determination of this location is based on the assumption that there is a relationship between the use of chemical laboratory facilities and the discipline of student chemistry learning and student achievement in chemistry.

\subsection{Population and Sample}

In this study, the authors took all students of class XII Sciences of SMA Negeri 1 Sorong as the study population. To find the number of samples in this study the authors used guidance from the Harry King Nomogram [8] with a $95 \%$ confidence interval. If the line drawn from the number 144 (population number) passes through the error rate of 0.05 , it is found that the point is above the number 65 and below the number 70 , this point is approximately $67 \%$. Thus the number of samples taken was 0.67 x $144=96.5$, or rounded to 97 . So the samples used in this study were 97 students.

To take the sample, the writer uses Proportional Random Sampling technique, where proportional random sampling, with the sample size used for each class, is a class XII Science Core with 17 students, X Science 1 has 26 students, class XII Science 2 has 27 students, and class XII Science 3 as many as 27 students.

\subsection{Data Collection Techniques}

\subsubsection{Questionnaire Method}

To fill data on the use of chemical laboratory facilities and student chemistry learning discipline, a Likert scale is used, with the form of response choices Very Frequently (SS), Often (S), Sometimes (KK), Rarely (J), Never (TP). For answers to favorable items are given a score of 5-1, where the response Very Often (SS) is given a score of 5, Often (S) is given a score of 4, Sometimes (KK) is given a score of 3, Rarely (J) is given a score of 2, Never (TP) is given a score of 1 . On the contrary, for the answer item unfavorable (in the form of a negative statement) given a score of 1-5, where the response Very Often (SS) is given a score of 1 , Often (S) is given a score of 2, Sometimes (KK) is given a score 3, Rarely $(\mathrm{J})$ was given a score of 4 , Never (TP) was given a score of 5 .

\subsubsection{Documentation methods}

This documentation method was carried out to obtain 
data about the chemistry learning achievement of student's class XII Science of SMA Negeri 1 Sorong.

\subsection{Data Types}

The types of data that will be used in this study are primary data and secondary data. In this study, primary data is the answer to the questions in the research questionnaire given directly to students of class XII Science SMA Negeri 1 Sorong. Secondary data is data obtained from other sources outside of direct research in the form of written documents that can support primary data, in this study secondary data is the result of MID scores from student's class XII science of SMA Negeri 1 Sorong.

\subsection{Test Validity and Reliability of Instruments}

\subsubsection{Item Validity}

The validity in this study was used to measure the validity of the questionnaire variables of the utilization of chemical laboratory facilities and the discipline of learning chemistry. In this study, the validity of the questionnaire was tested using the Product Moment Correlation equation by Pearson [9].

\subsubsection{Instrument Reliability}

Reliability test is used here to determine the consistency of the measuring instrument, whether the measuring instrument used is reliable and remains consistent if the measurement is repeated. To test the reliability of the instrument, Alpha Cronbach is used. [10]

\subsection{Data Analysis Techniques}

Techniques for analyzing data used in this study are statistical analysis techniques, through descriptive analysis, and correlation analysis [13]. To analyze the data, the author uses SPSS for Windows Version 16.0.

\subsubsection{Descriptive Analysis}

Descriptive analysis according to [11] is used to analyze data by describing data that has been collected as it is without intention to make conclusions that apply to the public or generalization. The measures used in this descriptive analysis are the mean, standard deviation, minimum score and maximum score.

\subsubsection{Pearson Correlation Analysis}

Correlation analysis is used to determine the hypothesized relationship between the dependent variable and the independent variable. This analysis is used to determine the relationship between students' chemistry learning discipline and students' chemistry learning achievements using SPSS version 16.0.

\section{Result}

\subsection{Research Description}

This research was carried out in SMA Negeri 1 Sorong on Jalan Danau Toba No. 2 Sorong. SMA Negeri 1 Sorong have 3 study programs for class XII, namely the Natural Sciences (IPA) program, the Social Sciences (IPS) program and the Language program, with a varied number of students in each class.

In this study, the data was taken by giving questionnaires or questionnaires to students of class XII science study programs. The questionnaire used during the study consisted of 28 items for the variable utilization of chemical laboratory facilities and 30 items for the discipline of student chemistry learning. The type of questionnaire used in this study is a closed questionnaire which has been provided with five alternative answers to choose from.

\subsection{Data Analysis}

\subsubsection{Descriptive Analysis of Utilization of Chemical Laboratory Facilities}

The classification of the frequency distribution of the use of chemical laboratory facilities for students of class XII Science in SMA N 1 Sorong is shown in Table 4.1

From Table 4.1, it appears that the use of chemical laboratory facilities to support the teaching and learning process is in the moderate to high category with a large percentage of utilization each of $31.96 \%$. This result can also be seen from the spread of an average of 78.05 which falls in the medium category, while the score varies from a small score of 30 in a very low category and a score of 120 in a very high category overall.

Table 4.1. Description of Frequency Use Chemical Laboratory Facilities

\begin{tabular}{|c|c|c|c|c|c|c|c|}
\hline Kategori & Interval & F & $\begin{array}{c}\text { Persen } \\
{[\%]}\end{array}$ & $\bar{x}$ & $S$ & Min & Maks \\
\hline Sangat Tingei (ST) & $100 \leq x<120$ & 16 & $16,49 \%$ & \multirow{5}{*}{78,05} & \multirow{5}{*}{18,70} & \multirow{5}{*}{30} & \multirow{5}{*}{120} \\
\hline Tingei ( $T$ ) & $80 \leq x<100$ & 31 & $31,96 \%$ & & & & \\
\hline Sedang (S) & $62 \leq x<80$ & 31 & $31,96 \%$ & & & & \\
\hline $\operatorname{Rendah}(\mathbb{R})$ & $43 \leq x<62$ & 17 & $17,53 \%$ & & & & \\
\hline Saneat Rendah ISR & $24 \leq x<43$ & 2 & $2.06 \%$ & & & & \\
\hline
\end{tabular}




\subsubsection{Analysis of Description of Discipline in Learning Chemistry}

The classification of the frequency distribution of the discipline of learning chemistry for students of class XII Science in SMA N 1 Sorong is presented in Table 4.2

Table 4.2. Description of the Frequency Discipline in Learning Chemistry

\begin{tabular}{|c|c|c|c|c|c|c|c|}
\hline Kategori & Interval & $\mathrm{F}$ & $\begin{array}{c}\text { Persen } \\
{[\%}\end{array}$ & $\bar{x}$ & $S$ & Min & Maks \\
\hline Sangat Tingei (ST) & $95 \leq x<115$ & 27 & $27,84 \%$ & \multirow{5}{*}{88,18} & \multirow{5}{*}{12,12} & \multirow{5}{*}{54} & \multirow{5}{*}{114} \\
\hline Tingei (T) & $77 \leq x<95$ & 54 & $55,67 \%$ & & & & \\
\hline Sedang $\mid \mathrm{S}$ | & $59 \leq x<77$ & 15 & $15,46 \%$ & & & & \\
\hline Rendah $(R)$ & $41 \leq x<59$ & 1 & $1.03 \%$ & & & & \\
\hline Saneat Rendah /SR & $23 \leq x<41$ & 0 & $0 \%$ & & & & \\
\hline
\end{tabular}

Table 4.2 shows that the discipline level of learning chemistry in students is in the high category (55.67\%). This result can also be seen from the magnitude of the average value of 88.18 which falls in the high category. Furthermore, from Table 4.3 it can be seen that the scores obtained varied from the lowest score of 54 in the low category and the highest score of 114 in the very high category.

\subsubsection{Analysis of Description of Chemistry Learning Achievement}

The classification of the frequency distribution of the chemistry learning achievement of students in class XII Science in SMA N 1 Sorong is presented in Table 4.3 below.

Table 4.3. Description of Frequency Learning Chemistry

\begin{tabular}{|c|c|c|c|c|c|c|c|}
\hline Kategori & Interval & F & $\begin{array}{c}\text { Persen } \\
(\%)\end{array}$ & $\bar{x}$ & $S$ & Min & Maks \\
\hline Sangat Tinggi (ST) & $80 \leq x<90$ & 26 & $26,80 \%$ & \multirow{5}{*}{71,19} & \multirow{5}{*}{11,83} & \multirow{5}{*}{40} & \multirow{5}{*}{90} \\
\hline Tinggi (T) & $70 \leq x<80$ & 48 & $49,48 \%$ & & & & \\
\hline Sedang (S) & $60 \leq x<70$ & 8 & $8,25 \%$ & & & & \\
\hline Rendah (R) & $50 \leq x<60$ & 13 & $13,40 \%$ & & & & \\
\hline Sangat Rendah (SR) & $40 \leq x<50$ & 2 & $2,06 \%$ & & & & \\
\hline
\end{tabular}

From Table 4.3 it appears that the chemistry learning achievement of students of class XII science in SMA Negeri 3 Sorong was in the high category (49.48\%), meaning that 48 out of 97 students had good achievements. This result can also be seen from the magnitude of the average value of 71.19 which falls in the high category, while the values obtained varied from the lowest value of 40 in the very low category and the highest score of 90 in the very high category.

\subsection{Test Validity and Reliability}

\subsubsection{Test Validity}

Based on the results of the calculation of the validity of the two variables from the two questionnaires used obtained 11 items that are not valid. In the questionnaire for the utilization of chemical laboratory facilities, there were 4 items that were invalid from a total of 28 questions. These invalid questions have a range of validity coefficients ranging from 0.058 to 0.187 , while valid items have a range of validity coefficients from 0.322 to 0.727 . While the validity test results for the discipline of learning chemistry, there are 7 items that are not valid from a total of 30 questions. Invalid questions have a validity coefficient range of $0.142-0.270$, while valid items have a range of validity coefficients of $0.311-0.562$. Validity test for questionnaire utilization of chemical laboratory facilities obtained 24 valid items and 4 invalid items from 28 items statement given to respondents. Invalid items are only in the sub concepts of classical learning activities with unfavorable questions, 4 items are 9, 10, 11, and 16.

While for the results of the validity test for the discipline of studying chemistry questionnaire from 30 items given statements obtained 23 valid items and 7 invalid items. 5 items that are not valid are in the sub-discipline concept in the class, namely in item 17 for the type of favorable questions while 16, 19, 20 and 30 for the type of unfavorable questions. However, the remaining invalid items are in the disciplinary sub concepts in the laboratory, namely in item 7 for favorable questions and item 4 for unfavorable questions. 


\subsubsection{Reliability Test}

The reliability test data for the utilization of chemical laboratory facilities with a total of 28 items obtained the reliability coefficient $\alpha=0.915$ and the reliability coefficient $\alpha$ after 4 invalid items were removed at $\alpha=$ 0.934, and according to George and Mallery, the magnitude of that number was included in the instrument category which had reliability in very high category.

Furthermore, the reliability test data for chemical learning discipline with 30 items obtained the reliability coefficient $\alpha=0.861$ and the reliability coefficient $\alpha$ after 7 invalid items were removed at $\alpha=0.867$; and according to George and Mallery, the magnitude of that number was included in the instrument category which had reliability in the high category.

\subsection{Normality Test}

Normal level test results for data on the use of chemical laboratory facilities and chemical learning discipline with the Kolmogrorov-Smirnov test are normal with a significance of $0.200>0.05$.

\subsection{Linearity Test}

The results of the linearity discipline test of chemistry learning with chemistry learning achievement have a linear relationship, which is indicated by the significance value of the two variables of 0.130 . Because the significance (linearity) is greater than 0.05 , it can be concluded that between the disciplines of chemistry learning and chemistry learning achievement there is a linear relationship.

\subsection{Correlation Analysis between Research Variables}

\subsubsection{Correlation between Utilization of Chemistry Laboratory Facilities and Chemistry Learning Achievement}

Data is processed using Pearson Product Moment correlation because the data meet the requirements of normal and linear. The results of calculation of Pearson Product Moment correlation using SPSS 16.0 for the utilization of chemical laboratory facilities with chemistry learning achievement shows the correlation coefficient (r) between the utilization of chemical laboratory facilities with student chemistry learning achievements of -0.160 with $\mathrm{p}=0.059$, and with the direction of negative correlation. With guidelines using a significance level of $5 \%$ obtained $\mathrm{p}=0.059>0.05$, which means that the use of laboratory facilities is not significantly related to student chemistry learning achievement.

This means that the use of chemical laboratory facilities often or not will be accompanied by an increase or decrease in student chemistry learning achievement. The results of this study are differ from Sobiroh findings [12] where the results of his study stated that the use of laboratory can improve student learning outcomes in grade 2 SMA Banjarnegara.

This difference is influenced by several internal and external factors. Internal factors include: 1) Interest, where students utilize chemical laboratory facilities only as a necessity that must be done during the process of learning chemistry at school without any more curiosity than students when studying chemistry. 2) Attention, students who have high attention in learning will produce a better level of understanding and ability so that without utilizing chemical laboratory facilities students are able to achieve good learning achievement. While external factors that influence this relationship are the use of chemical laboratory facilities as classrooms. Another factors is the existence of more theoretical learning evaluation without regard to the process skills provided while student utilizing the laboratory.

\subsubsection{Correlation between Chemistry Learning Discipline and Student Chemistry Learning Achievement}

The results of Pearson Product Moment correlation calculations using SPSS 16.0 for the discipline of learning chemistry with chemistry learning achievement shows the correlation coefficient (r) between the discipline of learning chemistry with student chemistry learning achievement of 0.146 with $p=0.076$, and with the direction of a positive correlation. With the guidelines using a significance level of $5 \%$ obtained $p=0.076>0.05$, the correlation between chemical learning discipline with chemistry learning achievement is declared insignificant. Thus it can be explained that the discipline of learning chemistry is not significantly related to student chemistry learning achievement.

This research is different from the research conducted by Wibowo [14] which states that there is a significant relationship between learning discipline with student achievement in class VIII SMP N 1 Getasan, where correlation coefficients are 0.136 and $\mathrm{P}=0.024$. This means that the discipline of chemistry learning for students of class XII IPA SMA N 1 Sorong is a form of discipline that does not originate from the students' awareness of themselves, but comes from outside themselves which forces student to become disciplined. Tu'u [15] says that, there are four dominant factors that influence and shape discipline, namely: self-awareness, obedience and obedience, educational tools, and punishment.

\subsection{Hypothesis Test}

Based on the formulation of the hypothesis, the tested statistical hypotheses are successively as follows:

1. 1. H0: $r_{x y} \leq 0$. There is no positive and significant relationship between the use of chemical laboratory facilities and the chemistry learning achievement of student's SMA Negeri 1. 
Hi: $\quad r_{x y}>0$.There is a positive and significant relationship between the use of chemical laboratory facilities with the chemistry learning achievement of Student's SMAN 1 Sorong.

2. 2. $\mathrm{H} 0: \mathrm{r}_{\mathrm{xy}} \leq 0$. There is no positive and significant relationship between student learning discipline with chemistry learning achievement of Student's SMAN 1 Sorong.

Hi: $\quad r_{x y}>0$ There is a positive and significant relationship between student learning discipline with chemistry learning achievement of Student's SMAN 1 Sorong.

From the results of the analysis, it was found that:

1. The correlation coefficient between the Utilization of Chemistry Laboratory Facilities and Student Chemistry Learning Achievement of -0.160 with $\mathrm{p}=0.059>0.05$. Because $\mathrm{r}_{\mathrm{xy}} \leq 0$ means that Ho is accepted and $\mathrm{Hi}$ is rejected, which means there is no positive and significant relationship between the Utilization of Chemistry Laboratory Facilities and Chemistry Learning Achievement of students in class XII Science of SMA N 1 Sorong.

2. The correlation coefficient between Chemistry Learning Discipline with Student Chemistry Learning Achievement of 0.146 with $\mathrm{p}=0.076>$ 0.05 . Because $r_{x y} \leq 0$ means that Ho is accepted and $\mathrm{Hi}$ is rejected, which means there is no positive and significant relationship between Chemistry Learning Discipline and Chemistry Learning Achievement of students in class XII Science of SMA N 1 Sorong.

\section{Conclusions}

Research on the relationship between the use of chemical laboratory facilities and the discipline of learning chemistry with student achievement in chemistry can be concluded: There is no positive and significant relationship between the Utilization of Chemical Laboratory Facilities and Discipline of Learning Chemistry with Chemistry Learning Achievement in Class XII Science students of SMA N 1 Sorong, which means that the high and low utilization of chemical laboratory facilities and the discipline of student chemistry learning does not affect student achievement in chemistry in the context of this study.

\section{REFERENCES}

[1] Sanjaya. W. Dr. Mpd. 2006. Strategi Pembelajaran Berorientasi Standar Proses Pendidikan. Jakarta: Kencana
[2] Amien, M. 1987. Mengajarkan IPA dengan Menggunakan Metode Discovery dan Inquiry. Jakarta : Depdikbud Dirjen Dikti.

[3] Penner, D. E., Lehrer, R., \& Schauble, L. 1998. From Physical Models To Biomechanics: A Design Based Modeling Approach: The Journal of The Learning Science

[4] Hofstein, A., \& Naaman, R. M. 2007. The laboratory in science education: the state of the art. Journal The Royal Society of Chemistry

[5] Nakhleh, Mary B. 1994. Chemical education research in the laboratory environment : How can research uncover, What student are learning?. Journal of Chemical Education, 17, (3), 201 - 205.

[6] Rahayu. W. S. 2010. Metode Eksperimen Sebagai Upaya Meningkatkan Prestasi Belajar IPA dalam Sub pokok Bahasan "Pertumbuhan Pada Tumbuhan" Pada Siswa Kelas II SD Negeri 1 Sumberejo Kecamatan Kerjo Kabupaten Karanganyar Tahun Pelajaran 2009/2010. Surakarta: FKIP UMS

[7] Sakdiyah, E. M. 2006. Pengaruh Motivasi, Disiplin dan Partisipasi Siswa Dalam Pembelajaran Terhadap Prestasi Belajar Akuntansi Siswa Kelas XI SMA Negeeri 1 Tayu Pati Semester II tahun ajaran 2006/2007. Semarang: FE. UNNES

[8] Sugiyono. 2017. Statistika untuk Penelitian. Bandung: Alfabeta

[9] Budiyono. Drs. 2003. Metodologi Penelitian Pendidikan: Sebelas Sebelas Maret University Press

[10] Priyatno, Dwi. 2009. Mandiri Belajar SPSS, Untuk Analisis Data dan Statistik. Jakarta: Mediakom

[11] Sugiyono. 2017. Metode Penelitian Kuantitatif, Kualitatif dan R \& D. Bandung: Alfabeta

[12] Sobiroh A. 2006. Pemanfaatan Laboratorium Untuk Meningkatkan Hasil Belajar Biologi Siswa Kelas 2 SMA Se-Kabupaten banjarnegara Semester 1 Tahun 2004/2005. Semarang: UNNES

[13] VAN HARLING, VINA N., and Markus Dwiyanto Tobi. "Analisis Hubungan Motivasi Kerja, Kompetensi Dosen, Kepemimpinan, Lingkungan Kerja Dan Komitmen Profesi Terhadap Kinerja Dosen Politeknik Katolik Saint Paul Sorong." SOSCIED 1.1 (2018): 46-56.

[14] Wibowo A. Bekti. 2006. Hubungan antara gaya belajar, disipilin belajar dengan prestasi belajar siswa kelas VIII SMP N 1 getasan. Salatiga: FKIP UKSW

[15] Tu’u, Tulus. 2004. Peran Disiplin pada Perilaku dan Prestasi Siswa. Jakarta: Grasindo

[16] A. Buchori, P. Setyosari, I. Wayan Dasna, and S. Ulfa, "Developing character building learning model using mobile augmented reality on elementary school student in Central Java,” Glob. J. Pure Appl. Math., vol. 12, no. 4, pp. 3433-3444, 2016.

[17] Sunandar, A. Buchori, N. D. Rahmawati, and W. Kusdaryani, "Mobilemath (mobile learning math) media design with seamless learning model on analytical geometry course,” Int. J. Appl. Eng. Res., vol. 12, no. 19, pp. 8076-8081, 2017. 
[18] Sunandar Buchori A and Rahmawati N D, 2016 Development of media kocerin (Smart box interactive) to learning mathematics in Junior High School Glob. J. Pure Appl. Math. 12, 6 p. 5253-5266. 